\title{
PROFIL BUDIDAYA DAN KELEMBAGAAN PEMASARAN RUMPUT LAUT (Grasillaria $S p$ ) DI KECAMATAN MUARA GEMBONG, KABUPATEN BEKASI, JAWA BARAT
}

\author{
*Rismutia Hayu Deswati dan Estu Sri Luhur \\ Balai Besar Penelitian Sosial Ekonomi Kelautan dan Perikanan \\ Gedung Balitbang KP I Lt. 4 \\ Jalan Pasir Putih Nomor 1 Ancol Timur, Jakarta Utara \\ Telp: (021) 64711583 Fax: 64700924 \\ *e-mail: rismutia.hd@gmail.com \\ Diterima 7 Maret 2014- Disetujui 25 Mei 2014
}

\begin{abstract}
ABSTRAK
Rumput laut Gracilaria sp di Kecamatan Muara Gembong, Kabupaten Bekasi, Jawa Barat dibudidayakan di tambak dengan sistem polikultur dengan Ikan Bandeng atau Udang. Namun, permasalahan terkait dengan sulitnya pembudidaya mengakses harga dan informasi serta sulitnya memenuhi kualitas rumput laut yang diminta konsumen masih dihadapi oleh pembudidaya rumput laut. Kajian ini bertujuan untuk menggambarkan kegiatan budidaya rumput laut dan rantai pemasaran mulai dari hulu sampai hilir di Kecamatan Muara Gembong, Kabupaten Bekasi, Jawa Barat. Kajian ini dilakukan pada tahun 2014 dengan menggunakan metode survei melalui observasi dan wawancara dengan kuesioner terstruktur. Data yang digunakan adalah data primer terkait kegiatan usaha rumput laut dan data sekunder terkait dokumen penunjang dari Dinas Kelautan dan Perikanan Kabupaten Bekasi. Data yang terkumpul kemudian dianalisis secara deskriptif kualitatif. Hasil kajian menunjukkan bahwa terdapat dua saluran pemasaran rumput laut, yaitu (1) pembudidaya menjual ke pedagang pengumpul kemudian dilanjutkan ke PPTP lalu dijual ke perusahaan agar-agar; dan (2) pembudidaya menjual ke pengumpul kemudian dilanjutkan ke pedagang besar di luar Kabupaten Bekasi. Kajian juga menunjukkan adanya masalah kualitas rumput laut yang masih termasuk kelas 2 dan terjadinya ketimpangan informasi sehinggapembudidaya sulit mengakses informasi harga dan pasar. Oleh karena itu, peran pemerintah daerah diperlukan dalam memperkuat koordinasi antar stakeholder daerah dalam rangka mengembangkan budidaya rumput laut dengan sistem polikultur ini.
\end{abstract}

Kata kunci: rumput laut, Muara Gembong, kelembagaan, pemasaran

\section{Abstract : Aquaculture and Marketing Institutional Profile of Seaweed in Muara Gembong, Bekasi District, West Java by Rismutia Hayu Deswati dan Estu Sri Luhur}

Seaweed (Gracilaria sp) in Muara Gembong, Bekasi, West Java is cultured in ponds with a polyculture system with fish or shrimp. However, difficulty of price information access and quality of seaweed to meet industrial requirement are still obstacles for seaweed farmers. Those seaweed is distributed through two types of marketing channels namely inside and outside of Bekasi District. This study aimed to describe activities of seaweed farming and marketing chain from upstream to downstream in Muara Gembong, Bekasi District, West Java. It was conducted in 2014 with survey method through observation and interviews with a structured questionnaire. Data used is primary data related to business activities of seaweed and secondary data related to supporting documents from Department of Marine and Fisheries in Bekasi Regency. That data analyzed by descriptive qualitative. Results showed that there are two marketing channels seaweed: (1) farmers sold to traders and then proceed to PPTP and then sold to companies agar; and (2) farmers sold to collectors then proceed to wholesalers outside Bekasi. This study also indicated a problem with quality of seaweed which still belongs to the class 2 and inequality of information that farmers have difficulty accessing information and market prices. The role of local government is need to improve coordination among local stakeholder to develop seaweed farming by using this polyculture system.

Keywords : seaweed, Muara gembong, institusional, marketing

\section{PENDAHULUAN}

Rumput laut beberapa waktu terakhir menjadi salah satu produk unggulan utama di perikanan budidaya sesuai dengan program yang dicanangkan pemerintah dalam rangka peningkatan produksi perikanan budidaya tahun 2010-2014. Hal ini karena rumput laut merupakan komoditas yang memiliki daya saing yang tinggi dan potensi pasar baik di dalam maupun luar negeri. Di Indonesia, rumput laut jenis Echeuma cottonii dan Gracillaria Sp adalah 2 jenis dari 550 jenis yang dibudidayakan. Pada awalnya budidaya rumput laut hanya terdapat di beberapa provinsi di Indonesia timur saja, namun sampai saat ini telah dibudidayakan di banyak lokasi di Indonesia termasuk di Kabupaten Bekasi. Kabupaten Bekasi merupakan salah satu andalan Jawa Barat penghasil rumput laut dengan produksi 7.000 ton dari total 10.000 ton hasil perikanan budidaya Kabupaten Bekasi (80\%) (Dinas PKP Kabupaten Bekasi, 2013).

Dalam rangka pemanfaatan peluang pengembangan budidaya rumput laut dengan sistem polikultur di Kabupaten Bekasi, makalah ini bertujuan untuk menggambarkan kegiatan budidaya rumput laut dan rantai pemasaran mulai dari hulu sampai hilir di Kecamatan Muara Gembong, Kabupaten Bekasi, Jawa Barat. 


\section{METODOLOGI}

Metode penelitian adalah bagaimana secara berurut suatu penelitian dilakukan yaitu dengan alat apa dan prosedur bagaimana suatu penelitian dilakukan (Nazir, 2003). Penelitian ini dilakukan dengan metode survei di 2 desa yaitu Desa Pantai Mekar dan Desa Pantai Sederhana yang terdapat di Kecamatan Muara Gembong. Survei dilakukan dengan observasi dan wawancara dengan menggunakan kuesioner terstruktur mengenai kegiatan perikanan budidaya terutama rumput laut yang baru berkembang di kecamatan ini. Data primer yang dikumpulkan merupakan hasil wawancara dengan pembudidaya rumput laut, pengumpul dan staf Dinas Peternakan, Kelautan dan Perikanan Kabupaten Bekasi, sedangkan data sekunder diperoleh dari hasil dokumentasi dinas. Data yang terkumpul kemudian dianalisis secara deskriptif untuk menggambarkan variabel-variabel yang ditemukan di lapang.

\section{Profil Kecamatan Muara Gembong}

Kabupaten Bekasi merupakan wilayah yang terletak di perbatasan Jakarta, Karawang dan Bogor. Kabupaten Bekasi memiliki garis pantai 72 kilometer, dan terdapat tiga kecamatan di wilayah utara yang membentang dari perbatasan Jakarta sampai perbatasan Karawang. Ketiga kecamatan tersebut adalah Kecamatan Muara Gembong, Kecamatan Taruma Jaya dan Kecamatan Babelan yang merupakan wilayah pesisir di Kabupaten Bekasi. Berdasarkan data dari Dinas Peternakan, Kelautan dan Perikanan Kabupaten Bekasi, Kecamatan Muara Gembong merupakan wilayah pesisir dan perikanan terbesar dibandingkan dua kecamatan lainnya.

Kecamatan Muara Gembong memiliki luas wilayah sebesar 154,6 km² yang terdiri dari 6 (enam) desa, yaitu Desa Pantai Mekar, Desa Pantai Sederhana, Desa Jayasakti, Desa Pantai Harapan Jaya, Pantai Bakti dan Pantai Bahagia. Dilihat dari segi geografis, Kecamatan Muara Gembong terletak pada posisi $5^{\circ} 57^{\prime} 1,0^{\prime \prime}-6^{\circ} 2^{\prime}$ 24,5" Lintang Selatan dan $107^{\circ} 1^{\prime} 29,6^{\prime \prime}-107^{\circ} 5^{\prime} 59,6^{\prime \prime}$ Bujur Timur. Kecamatan Muara Gembong merupakan wilayah administratif Kabupaten Bekasi yang berjarak sekitar $100 \mathrm{~km}$ dari Ibukota dengan batas-batas sebagai berikut:

- Sebelah Utara berbatasan dengan Laut Jawa;

- Sebelah Selatan dengan Kecamatan Babelan, Sukawangi dan Cabangbungin;

- Sebelah Barat berbatasan dengan Laut Jawa;

- Sebelah Timur berbatasan dengan Kabupaten Karawang.

Mata pencaharian penduduk Muara Gembong sebagian besar adalah dari sektor pertanian dengan komoditas utama padi, palawija dan perikanan $(47,67 \%)$ dan sisanya tersebar di sektor non pertanian seperti buruh pabrik, pedagang, buruh tani, TKI di luar negeri (52,33\%). Berdasarkan letak geografisnya yang berdekatan dengan Teluk jakarta dan aliran Sungai Citarum menjadikan sekitar $90 \%$ mata pencaharian penduduknya dari usaha perairan yaitu nelayan tangkap (688 orang) dan pembudidaya tambak (4.262 orang).

Mata pencaharian sebagai petani tambak banyak diminati oleh penduduk di Kecamatan Muara Gembong karena sarana dan prasarana yang terdapat di wilayah ini sangat mendukung, seperti kondisi wilayah, iklim dan jenis tanahnya. Faktor lain yang juga mendorong terbentuknya pertanian tambak adalah harga rata-rata dari hasil budidaya tambak (budidaya udang, bandeng, rumput laut) yang cukup tinggi. Sementara peluang usaha-usaha lain yang berbentuk non perikanan masih sulit untuk dikembangkan karena letak wilayah pesisir ini sulit dijangkau ke pusat perekonomian melalui jalan darat, sedangkan transportasi laut yang tersedia masih sangat sederhana.

\section{Budidaya Rumput Laut di Kecamatan Muara Gembong}

Secara umum, budidaya perikanan merupakan bentuk pemeliharaan dan penangkaran berbagai macam hewan atau tumbuhan perairan, yang dimulai dari proses pemeliharaan untuk meningkatkan produksi, seperti penebaran yang teratur, pemberian pakan, perlindungan terhadap pemangsa (predator) pencegahan terhadap serangan penyakit dan pemanenan (Khurio, 2011). Budidaya rumput laut masuk kategori perikanan budidaya karena kegiatan di dalamnya mengandung bentuk- bentuk yang telah disebutkan diatas yaitu mulai dari proses pemeliharaan, pencegahan terhadap serangan penyakit dan pemanenan.

Luasan lahan budidaya tambak di Kecamatan Muara Gembong sebesar 10.189 Ha yang terbagi menjadi 3 sesuai dengan komoditas unggulan yaitu rumput laut, udang windu dan bendeng yang diproduksi kecamatan tersebut. Luas lahan yang digunakan untuk budidaya rumput laut adalah $1000 \mathrm{Ha}$, budidaya udang windu sebesar 31, $06 \mathrm{Ha}$ dan budidaya bandeng seluas $92,53 \mathrm{Ha}$, dan saat dilakukan budidaya polikultur antara bandeng dan rumput laut. Kegiatan budidaya tambak di Muara Gembong masih dilakukan secara tradisional dengan menggunakan pakan alami sebagai makanan bandeng dan udang. Pembudidaya menggunakan pupuk urea sebagai bahan untuk menumbuhkan pakan alami di sekitar tambak. Siklus budidaya untuk ketiga komoditas tersebut berbeda-beda. Siklus untuk bandeng dibudidayakan selama $6-7$ bulan, udang dibudidayakan selama 4 bulan dan rumput laut dibudidayakan selama 4- 5 bulan .

Budidaya rumput laut dikenal masyarakat Muara Gembong berkat adanya pelatihan dan pendampingan mengenai budidaya rumput laut yang baik dan benar oleh Dinas PKP Kabupaten Bekasi yang dilakukan pada tahun 2009. Jenis rumput laut yang dibudidayakan adalah Gracilaria $S p$ dengan waktu pemeliharaan yang baik pada kisaran bulan Desember - Maret. Bibit rumput laut saat ini bisa diperoleh dengan mudah dari 
dalam Muara Gembong sendiri dengan harga jualnya Rp $2.500 / \mathrm{kg}$. Setiap pembudidaya saat panen bisa menghasilkan $3-5$ ton rumput laut basah yang kemudian dikeringkan menjadi 2 ton rumput laut kering setelah itu dijual.

Pemeliharaan rumput laut dilakukan secara polikultur. Polikultur rumput laut dengan ikan bandeng memerlukan 1000-2000 ekor/tambak dengan luas rata-rata 2-4 ha/petak. Benih ikan bandeng diperoleh dari Kabupaten Karawang. Sistem budidaya polikultur adalah pemanfaataan lahan dengan lebih dari satu organisme akuatik. Sistem ini meningkatkan efisiensi penggunaan lahan dan pendapatan pembudidaya secara berkesinambungan. Sistem polikultur didasari atas prinsip keseimbangan alam. Rumput laut berfungsi sebagai penghasil oksigen, tempat berlindung bagi ikan bandeng dari predator, dan menyerap $\mathrm{CO}_{2}$ terlarut hasil pernafasan ikan bandeng, sedangkan ikan bandeng akan membuang kotoran yang dapat dipakai sebagai nutrien oleh rumput laut (Silitonga,2013).

\section{Saluran Pemasaran Rumput Laut}

Budidaya rumput laut di tambak menjadi hal baru bagi masyarakat Muara Gembong namun usaha ini dipandang memiliki peluang dan potensi yang bagus baik dari sisi ketersediaan lahan maupun peluang pasar. Hal ini karena permintaan rumput laut semakin meningkat yang berasal dari dalam maupun luar Kabupaten Bekasi. Seluruh pekerjaan budidaya mulai dari persiapan lahan, pemasangan bibit, panen hingga pemasaran dikerjakan oleh laki-laki (suami) dan tidak ada pembagian kerja berdasarkan jenis kelamin.

Pemasaran adalah suatu proses kegiatan menyalurkan produk dari produsen ke konsumen sehinggapemasaran merupakan "ujung tombak" kegiatan ekonomi dalam agribisnis perikanan (Mahyudin, 2009). Dalam penelitian ini pemasaran dimaksudkan untuk penjualan hasil rumput laut sebagai bahan mentah dari pembudidaya hingga konsumen akhir. Rumput laut yang dihasilkan pembudidaya Muara Gembong awalnya memiliki satu saluran pemasaran yaitu dari pembudidaya dijual langsung ke pengumpul kemudian dari para pengumpul rumput laut tersebut disetorkan ke PPTP yang kemudian dilanjutkan ke perusahaan agar-agar (Gambar 1). Pedagang yang berperan dalam pemasaran rumput laut diantaranya adalah pedagang pengumpul dan PPTP (Paguyuban Petani Tambak Pantura), dimana pedagang pengepul berjumlah sekitar 1-2 orang yang menerima rumput laut dari 4-5 pembudidaya. Sementara itu PPTP merupakan paguyuban petambak baik rumput laut maupun komoditas lain yang anggotanya tersebar di daerah pantai utara Jawa (Pantura), yang fungsinya sebagai sarana pertukaran informasi pasar dan mencari solusi dari suatu permasalahan (Gambar 1)

Pada saat panen pembudidaya rumput laut kering dijual ke pengumpul dengan sistem pembayaran cash. Harga jual rumput laut kering sebesar Rp 6.000/kg sedangkan untuk harga basah sebesar Rp 1.500/kg kemudian oleh pengumpul rumput laut disalurkan ke PPTP (Paguyuban Petani Tambak Pantura) untuk dikumpulkan dengan rumput laut lainnya dan sampai mencapai 10 ton. Setelah itu rumput laut tersebut dijual ke perusahaan agar-agar dengan sistem pembayaran "tempo " atau dibayarkan 7 hari setelah rumput laut disetor oleh PPTP. Namun demikian, beberapa pembudidaya mencoba jalur pemasaran lain yaitu mengirim ke pedagang besar yang ada di Kabupaten Karawang. Hal ini dilakukan karena pembudidaya belum dapat memenuhi syarat kualitas rumput laut yang ditetapkan oleh perusahaan agar-agar tersebut.

Salah satu cara yang digunakan untuk meneliti kelembagaan pemasaran rumput laut yaitu dengan menggunakan analisis perilaku pasar. Menurut Puspitasari (2010) menggunakan pendekatan penentuan harga diperoleh hasil bahwa posisi tawar pembudidaya cenderung lemah atau rendah yang disebabkan oleh beberapa hal yaitu keterbatasan modal, lemahnya akses pasar dan keterbatasan informasi yang dimiliki oleh pembudidaya sehingga menyebabkan harga cenderung ditentukan oleh lembaga tata niaga yang lebih tinggi.

Permasalahan diatas telah menyebabkan saluran pemasaran lain terbentuk dandijadikan pilihan oleh para pembudidaya. Saluran pemasaran kedua menggambarkan bahwa rumput laut dari pembudidaya dijual ke pengumpul kemudian dijual ke luar kabupaten yaitu Kabupaten Karawang dan Majalengka (Gambar 2).

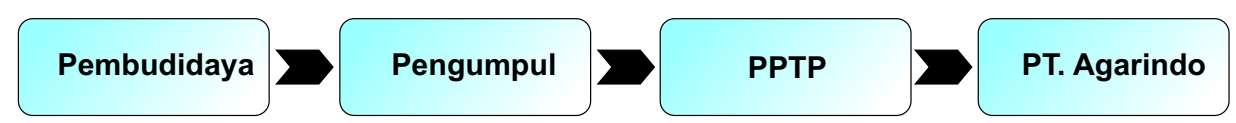

Gambar 1. Saluran Pemasaran Pola-1 Rumput Laut di Kecamatan Muara Gembong Sumber : Hasil pengamatan di lapang (2013)

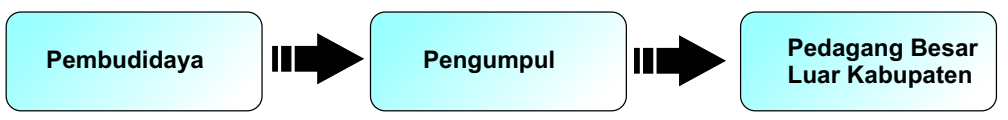

Gambar 2. Saluran Pemasaran Pola-2 Rumput Laut di Kecamatan Muara Gembong Sumber : Hasil pengamatan di lapang (2013) 
Dalam rantai tata niaga rumput laut terdapat pelaku-pelaku ekonomi yang berperan secara baik secara langsung maupun tidak langsung melakukan fungsi pemasaran. Menurut Adida (2014) salah satu fungsi pemasaran yang penting dilakukan oleh pelaku pemasaran dan juga pembudidaya adalah fungsi informasi pasar yaitu mencari informasi harga rumput laut di pasar umum sebelum melakukan transaksi penjualan.

Hasil penelitian ini menunjukkan bahwa tingginya potensi dan peluang usaha budidaya rumput laut di Kecamatan Muara Gembong masih belum menarik minat masyarakat untuk melakukan usaha tersebut. Hal ini disebabkan oleh beberapa hal diantaranya tingginya kualitas rumput laut yang diminta oleh pembeli dalam hal ini perusahaan masih terlalu sulit untuk dipenuhi oleh pembudidaya yang tidak memiliki hasil produksi banyak sehingga mereka mengalami kesulitan dalam mencari pasar. Penyebab lainnya adalah keterbatasan pembudidaya untuk mengakses penentuan harga dan informasi pasar lainnya. Selama ini terjadi information asymetrisme (ketimpangan informasi) karena informasi pasar dan harga hanya dimiliki oleh pelaku-pelaku tertentu dalam kelembagaan pemasaran yaitu pedagang pengumpul saja.

Adanya permasalahan tersebut diatas diharapkan dapatdiselesaikan dengan adanya campur tangan pemerintah daerah Kabupaten Bekasi untuk mengendalikan harga dan membuka peluang pasar serta memberikan pengetahuan tambahan mengenai budidaya rumput laut, pengolahan rumput laut dan manajemennya secara rutin. Hingga nantinya potensi ini bisa bermanfaat sebagai mata pencaharian alternatif bagi masyarakat Muara Gembong saat musim paceklik pada perikanan tangkap.

\section{KESIMPULAN DAN IMPLIKASI KEBIJAKAN}

\section{Kesimpulan}

Budidaya rumput laut dengan sistem polikultur mulai berkembang di Kecamatan Muara Gembong, Kabupaten Bekasi, Jawa Barat. Sistem ini dilakukan antara rumput laut dengan ikan bandeng dengan siklus budidaya yang berbeda yaitu rumput laut selama 4-5 bulan sedangkan bandeng selama 6-7 bulan. Pembudidaya menghasilkan 3-5 ton rumput laut basah atau jika sudah dikeringkan menjadi 2 ton setiap panennya (setelah 45 hari).

Terdapat dua saluran pemasaran rumput laut yaitu saluran pertama pembudidaya menjual ke pedagang pengumpul kemudian dilanjutkan ke PPTP lalu dijual ke perusahaan agar-agar. Saluran pemasaran kedua rumput laut yang dihasilkan oleh pembudidaya dijual ke pengumpul kemudian dilanjutkan ke pedagang besar yang ada di luar Kabupaten Bekasi.

\section{Implikasi Kebijakan}

Mengigat bahwa, masih terdapat permasalahan bagi para pembudidaya rumput laut untuk mengembangkan usahanya yaitu kualitas rumput laut masih termasuk kelas 2 dan terjadinya ketimpangan informasi atau dengan kata lain pembudidaya sulit untuk mengakses informasi harga dan pasar. Oleh karena itu dibutuhkan komitmen antara pemerintah Kabupaten Bekasi dengan para pembudidaya untuk melakukan koordinasi dalam mendukung pengembangan usaha budidaya rumput laut ini supaya bisa menjadi mata pencaharian alternatif bagi para nelayan di Muara Gembong.

\section{DAFTAR PUSTAKA}

Adida, K.Nirmala dan S. Harijati.2014. Efisiensi Pemasaran Benih Ikan Gurami (Oshpronemus Gouramy) Ukuran 'Nguku' ditinjau dari Keragaan Pasar di Kelurahan Duren Mekar dan Duren Seribu,Depok Jawa Barat. Jurnal Manajemen Perikanan dan Kelautan Vol. 1 No. 1, 2014, artikel 8.ISSN : 2356-3907

Dinas Peternakan Kelautan dan Perikanan Kabupaten Bekasi. 2013. Laporan Tahunan. Dinas Kelautan dan Perikanan Kabupaten Bekasi. Jawa Barat.

Mahyuddin, K. (2009). Panduan lengkap agribisnis ikan gurami. Jakarta: Penebar Swadaya.

Nazir, M. 2003. Metode Ilmiah. Ghalia Indonesia. Jakarta.

Puspitasari dan Yunita. 2010. Analisis Efisiensi Tataniaga pada Kelompok Usaha Budidaya Ikan Lele Sangkuriang (Clarias sp.) di Kecamatan Ciawi Kabupaten Bogor Provinsi Jawa Barat [skripsi]. Bogor: Fakultas Pertanian, Institut Pertanian Bogor.

Khurio, S. 2011. Budidaya Perikanan yang Baik dan Benar. Pusat Riset Perikanan Budidaya. http//budidaya perikanan.htm. (26 Oktober 2014).

Silitonga dan F.Suryani.2013.Keragaan Fenotipe Rumput Laut Gracilaria spp. Budidaya Polikultur pada Salinitas 6-18 g/kg di Tambak Muara Gembong, Bekasi. Skripsi. Departemen Budidaya Perairan Fakultas Perikanan dan IImu Kelautan. Institut Pertanian Bogor. 2013. 